P ISSN : 2503 - 1708

E ISSN : 2722 - 7340

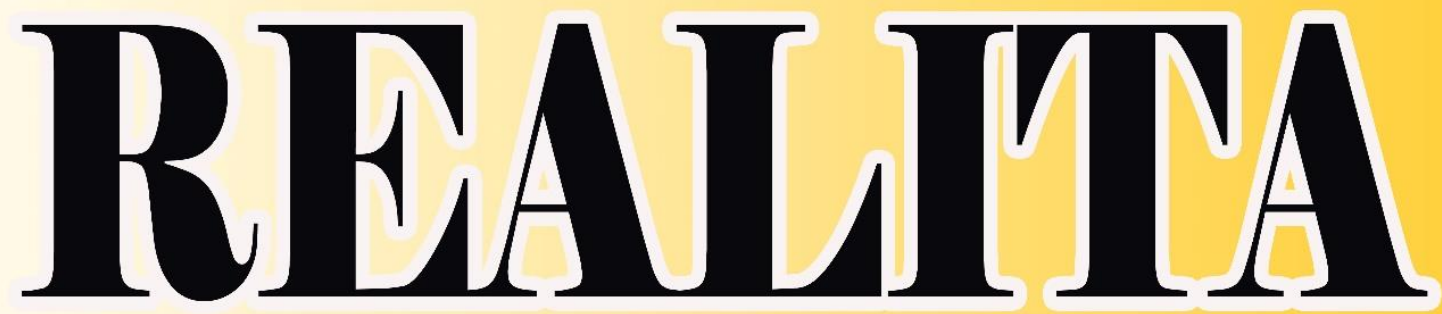

Jurnal Bimbingan dan Konseling

\begin{tabular}{|c|c|c|c|c|c|}
\hline JURNAL & VOLUME & NOMOR & EDISI & HALAMAN & P ISSN : 2503 - 1708 \\
REALITA & 6 & 2 & Oktober 2021 & $1326-1430$ & E ISSN : 2722 - 7340 \\
\hline
\end{tabular}

Diterbitkan oleh:

PROGRAM STUDI BIMBINGAN DAN KONSELING FAKULTAS ILMU PENDIDIKAN DAN PSIKOLOGI UNIVERSITAS PENDIDIKAN MANDALIKA 


\section{REALITA \\ BIMBINGAN DAN KONSELING \\ Jurnal Penelitian dan Pengembangan Pendidikan}

\section{DEWAN REDAKASI \\ Pelindung : Rektor Universitas Pendidikan Mandalika \\ : Dekan FIPP Universitas Pendidikan Mandalika \\ Penanggung \\ Jawab \\ : Kaprodi BK FIPP Universitas Pendidikan Mandalika \\ Editor}

Hariadi Ahmad, M.Pd

Universitas Pendidikan Mandalika

Associate Editor

Mustakim, M.Pd

Universitas Pendidikan Mandalika

Mujiburrahman, M.Pd

Universitas Pendidikan Mandalika

Ahmad Muzanni, M.Pd

Universitas Pendidikan Mandalika

M. Chaerul Anam, M.Pd

Universitas Pendidikan Mandalika

\section{Editorial Board}

Prof. Drs. Kusno, DEA., Ph.D

Universitas Negeri Jember Jawa Timur

Drs. Wayan Tamba, M.Pd

Farida Herna Astuti, M.Pd

Ichwanul Mustakim, M.Pd

Reza Zulaifi, M.Pd

Jessica Festi Maharani, M.Pd

Universitas Pendidikan Mandalika

Universitas Pendidikan Mandalika

Universitas Pendidikan Mandalika

Universitas Pendidikan Mandalika

Universitas Pendidikan Mandalika

\section{Reviwer}

Dr. I Made Sonny Gunawan, S.Pd., M.Pd

Universitas Pendidikan Mandalika

Dr. A. Hari Witono, M.Pd

Universitas Mataram NTB

Prof. Dr. Wayan Maba

Universitas Mahasaraswati Bali

Dr. Gunawan, M.Pd

Universitas Mataram NTB

Dr. Haromain, S.Pd., M.Pd.

Universitas Pendidikan Mandalika

Dr. Hadi Gunawan Sakti, M.Pd

Wiryo Nuryono, M.Pd

Hasrul, S.PdI., M.Pd

Dita Kurnia Sari, M.Pd

Dr. Roro Umy Badriyah. M.Pd., Kons

Universitas Pendidikan Mandalika

Universitas Negeri Surabaya Jawa Timur

STKIP Kie Raha Ternate Maluku Utara

UIN Sunan Ampel Surabaya Jawa Timur

Universitas PGRI Maha Dewa Bali

Ari Khusumadewi, M.Pd

Universitas Negeri Surabaya Jawa Timur 
M. Najamuddin, M.Pd

M. Samsul Hadi, M.Pd

Lalu Jaswandi, M.Pd

Eneng Garnika, M.Pd

Aluh Hartati, M.Pd

Drs. I Made Gunawan, M.Pd

Nuraeni, S.Pd., M.Si

Baiq Sarlita Kartiani, M.Pd

M. Zainuddin, M.Pd

Ahmad Zainul Irfan, M.Pd

Dra. Ni Ketut Alit Suarti, M.Pd

Asep Sahrudin, S.Pd., M.Pd

Suciati Rahayu Widyastuti, S.Pd., M.Pd

Rahmawati M, S.Pd., M.Pd

Ginanjar Nugraheningsih, S.Pd. Jas., M.Or

Dewi Ariani, S.Pd., M.Pd

St. Muriati, S.Pd., M.Pd

Uli Agustina Gultom, S.Pd., M.Pd

Indra Zultiar, S.Pd., M.Pd.
Universitas Pendidikan Mandalika

Universitas Pendidikan Mandalika

Universitas Pendidikan Mandalika

Universitas Pendidikan Mandalika

Universitas Pendidikan Mandalika

Universitas Pendidikan Mandalika

Universitas Pendidikan Mandalika

Universitas Pendidikan Mandalika

Universitas Pendidikan Mandalika

Universitas Pendidikan Mandalika

Universitas Pendidikan Mandalika

Univ. Mathla'ul Anwar Banten

Univ. Nahdlatul Ulama Cirebon

Universitas Muhammadiyah Kendari Sulawesi Tenggara

Universitas Mercu Buana Yogyakarta

Universitas Mahaputra Muhammad Yamin Solok Sumatera Barat

Universitas Bosowa Makassar Sulawesi Selatan

Universitas Borneo Tarakan Kalimantan Utara

Universitas Muhammadiyah Sukabumi Jawa Barat

\section{Alamat Redaksi:}

Redaksi Jurnal Realita Bimbingan dan Konseling (JRbk)

Program Studi Bimbingan dan Konseling

Fakultas Ilmu Pendidikan dan Psikologi Universitas Pendidikan Mandalika

Gedung Dwitiya, Lt. 3 Jalan Pemuda No. 59 A Mataram Telp. (0370) 638991

Email : realita@undikma.ac.id

Web : e-journal.undikma.ac.id

Jurnal Realita Bimbingan dan Konseling menerima naskah tulisan penulis yang original (belum pernah diterbitkan sebelumnya) dalam bentuk soft file, office word document (Email) atau Submission lansung di akun yang diterbitkan setiap bulan April dan Oktober setiap tahun.

Diterbitkan Oleh: Program Studi Bimbingan dan Konseling Fakultas Ilmu Pendidikan dan Psikologi Universitas Pendidikan Mandalika. 


\section{DAFTAR ISI}

Halaman

\section{Nuraeni dan Mastari}

Pengaruh Konseling Kelompok Terhadap Self Esteem Siswa Kelas XI di SMK Negeri 2 Kuripan

\section{Aprilia Yolanda, Ni Ketut Alit Suarti dan Ahmad Muzanni}

Pengaruh Body Shaming Terhadap Kepercayaan Diri Siswa SMA Negeri

1 Batulayar

$1342-1353$

\section{Hariadi Ahmad}

Hubungan Kestabilan Emosi dengan Kontrol Diri Siswa Sekolah Menegah Pertama

\section{Aluh Hartati}

Pengaruh Teknik Modeling Untuk Meningkatkan Empati Siswa

\section{Mustakim}

Pengaruh Teknik Cerita Terhadap Sikap Kemandirian Anak Pada Usia 5-6 Tahun

\section{Farida Herna Astuti dan Ichwanul Mustakim}

Keefektifan Bimbingan Kelompok dengan Teknik Role Playing untuk Meningkatkan Motivasi Belajar

\section{Mujiburrahman dan Soba Al-Qadri}

Hubungan Antara Kemampuan Kontrol Diri Dengan Penyusaian Diri Pada Siswa Kelas XI SMA Negeri 1 Taliwang

\section{Wiwiek Zainar Sri Utami}

Pengaruh Konseling Individu Terhadap Potensi Diri Anak Tunarungu di Sekolah Inklusi

\section{Baiq Nur'aini Cahya Khairani dan Ni Made Sulastri}

Pengaruh Layanan Konseling Humanistik Terhadap Perilaku Agresif pada Siswa Kelas XI IPS-4 di SMA Negeri 7 Mataram

\section{Najamudin}

Pengaruh Teknik Biblioterapi Terhadap Sikap Kemandirian Belajar Pada Siswa VIII SMP Negeri 5 Lembar

\section{Khaerul Huda}

Meningkatkan Pengetahuan dan Pemahaman Perilaku Hidup Bersih dan Sehat dimasa Covid 19 Melalui Metode Demontrasi pada Kelompok B di TK Negeri 01 Wanasaba 


\title{
PENGARUH LAYANAN KONSELING HUMANISTIK TERHADAP PERILAKU AGRESIF PADA SISWA KELAS XI IPS-4 DI SMA NEGERI 7 MATARAM
}

\author{
Oleh: \\ Baiq Nur'aini Cahya Khairani dan Ni Made Sulastri \\ Program Studi Bimbingan dan Konseling, Fakultas Ilmu Pendidikan dan Psikologi \\ Universitas Pendidikan Mandalika Mataram Nusa Tenggara Barat Indonesia \\ Email: baiqcahyakhaira@gmail.com; nimadesulastri@undikma.ac.id
}

\begin{abstract}
Abstrak: Perilaku agresif verbal merupakan suatu perilaku menyakiti orang lain dengan katakata yang berupa membentak, berbicara kasar, menghina. Maka peneliti melakukan penelitian tentang Pengaruh Layanan Konseling Humanistik Terhadap Perilaku Agresif Pada Siswa kelas XI IPS-4 di SMA Negeri 7 Mataram Tahun pelajaran 2020/2021. Tujuan dari penelitian ini adalah untuk mengetahui apakah ada pengaruh layanan konseling humanistik terhadap perilaku agresif pada siswa kelas XI IPS-4 di SMA Negeri 7 Mataram tahun pelajaran 2020/2021. Metode yang digunakan dalam penelitian ini adalah pendekatan eksperimen dengan desain penelitian one group pree test dan posttest design. Peneliti mengambil kelas XI IPS-4 dengan jumlah populasi 28 siswa dan mengambil sampel sebanyak 8 orang, karena peneliti menggunakan teknik simple random sampling, yang di mana pengambilan sampel dilakukan secara acak tanpa memperhatikan strata yang ada dalam populasi tersebut dengan mengambil skor paling tinggi pada karakteristik yang sudah ditentukan. Instrument yang digunakan dalam mengumpulkan data adalah metode interview, metode angket metode observasi dan metode dokumentasi. Analisis data yang digunakan adalah uji t-test, dengan hasil perhitungan yang didapatkan adalah nilai thitung sebesar 5,543 dan nilai $t_{\text {tabel }}$ dengan $\mathrm{N}=8-1=7$ dengan taraf signifikan $5 \%=2,365$. Maka dari itu hasil yang diperoleh dalam penelitian ini adalah nilai thitung lebih besar dari nilai $t_{\text {tabel }}$ dengan taraf signifikan $(5,543>2,365)$. Maka hipotesis nihil (Ho) ditolak sedangkan hipotesis akternatif (Ha) diterima, dengan demikian kesimpulan yang dapat diperoleh dalam penelitian ini adalah: Ada Pengaruh Layanan Konseling humanistik Terhadap Perilaku Agresif Pada Siswa Kelas XI Ips-4 di SMA Negeri 7 Mataram Tahun Pelajaran 2020/2021. Dan dapat dinyatakan bahwa hasil penelitian ini "signifikan".
\end{abstract}

\section{Kata kunci: konseling humanistik, perilaku agresif}

\section{PENDAHULUAN}

Peserta didik merupakan individu yang memilki karakteristik dan potensi yang berbeda-beda dalam proses perkembangannya, sehingga peserta didik memerlukan bantuan dalam mengenal jati dirinya, terutama di lingkungan sekolah dan masyarakat. Terkadang ada beberapa peserta didik yang berperilaku kurang baik, baik dari segi perilaku, sikap, tindakan, hingga ucapan. Peserta didik yang seperti ini biasanya dikatatakn peserta didik yang nakal, namun sebenarnya peserta didik yang berperilaku seperti itu juga dapat tergolong peserta didik yang memiliki perilaku agresif, seperti halnya peserta didik yang sering bersorak-sorak kepada teman, berkata kotor dan kasar, membentak hingga menghina dengan berbagai ejean, perilaku-perilaku seperti ini sudah jelas tergolong dalam perilaku agresif verbal yang dilakukan peserta didik. Tentunya perilaku agresif verbal yang dilakukannya dapat menghambat segala perkembangannya, baik dari segi intelegensi hingga pembentukan karakter pribadinya bahkan bisa menimbulkan masalah dalam dirinya dan lingkungan sekitarnya. Perilaku a gresif ini tidak memandang usia, maksudnya adalah 
setiap orang dengan usia anak-anak, remaja, dewasa hingga orangtua bisa saja berperilaku agresif. Maka dari itu sangat diperlukan bimbingan dan konseling untuk mengurangi perilaku agresif verbalnya tersebut dan tentunya dalam hal ini pendidikan sangat berperan penting dalam pembentukan karakter peserta didik.

Pendidikan Nasional berfungsi mengembangkan kemampuan dan membentuk manusia Indonesia yang bermartabat dalam rangka mencerdaskan kehidupan bangsa, bertujuan untuk mengembangkan potensi peserta didik agar menjadi manusia yang beriman dan bertaqwa kepada Tuhan Yang Maha Esa, berakhlak mulia, sehat, berilmu, cakap, kreatif, mandiri dan menjadi warga negara yang demokratis serta bertanggung jawab. Dapat dijelaskan bahwa dalam rangka mewujudkan manusia Indonesia yang bermartabat dan cakap serta berilmu ini dapat dikembangkan melalui kegiatan sekolah yaitu kegiatan intrakurikuler dan ekstrakurikuler, disamping itu bimbingan dan konseling juga ikut andil didalamnya, yakni membimbing siswa meraih pengembangan diri yang optimal sesuai dengan tahap perkembangan dan tuntutan lingkungan yang positif' (UU RI No 20, 2003: Pasal 3).

Kurikulum digunakan sebagai pedoman dalam penyelenggaraan kegiatan pembelajaran untuk mencapai tujuan pendidikan yang telah ditentukan. Dari semua itu tujuan dari setiap peserta didik yang datang ke sekolah tidak lain kecuali untuk belajar di kelas agar mendapatkan ilmu pengetahuan. Sebagian besar waktu yang tersedia harus digunakan oleh peserta didik untuk belajar, tidak mesti ketika di sekolah, di rumah pun harus ada waktu yang disediakan untuk kepentingan belajar. Tiada hari tanpa belajar adalah ungkapan yang tepat bagi peserta didik. Bimbingan dan konseling merupakan salah satu komponen pendidikan, selain itu pula bimbingan dan konseling merupakan suatu bantuan yang dapat diberikan individu ke individu lainnya baik secara langsung maupun tidak langsung dalam upaya membantu individu tersebut menyelesaikan persoalan yang sedang dihadapinya. Secara khususnya dalam kasus peserta didik yang memiliki perilaku agresif verbal sangat diperlukan bimbingan konseling dilakukan oleh seorang ahli (guru BK) dalam upaya membantu peserta didik mengembangkan potensi dirinya ataupun memcahkan masalahnya.

Berdasarkan SK Mendikbud No. 025/01/1995 tentang petunujuk teknis ketentuan pelaksanaan jabatan fungsional dan angka kreditnya bimbingan dan konseling adalah pelayanan bantuan untuk siswa baik secara optimal dalam bidang bimbingan pribadi, bimbingan sosial, bimbingan belajar, dan bimbingan karir melalui jenis layanan dan kegiatan pendukung, berdasarkan norma-norma yang berlaku. Konseling humanistik merupakan suatu pendekatan yang berfokus pada perkembangan kehidupan yang positif. Konseling humanistik memiliki konsep yang mengarah pada kehidupan sekarang yang akan sangat berpengaruh pada masa depan seseorang, berdasarkan perilaku sekarang yang bisa menentukan nasib masa depannnya (Corey dalam Fitri, 2019).

Melalui kegiatan konseling humanistik ini peserta didik akan diberikan pemahaman atas dirinya sebagai makhluk yang memiliki otoritas atas kehidupan dirinya, konseling humanistik juga akan membantu peserta didik untuk meningkatkan pemahaman atas dirinya melalui perasaan-perasaan mereka serta membantu peserta didik dalam membuat keputusan tentang hal-hal yang berkaitan dengan dirinya dan lingkungannya. Perilaku agresif verbal merupakan suatu perilaku yang dilakukan 
untuk menyakiti, mengancam atau membahayakan individu-individu atau objek-objek yang menjadi sasaran tersebut secara verbal atau melalui katakata dan langsung ataupun tidak langsung, seperti memaki, menolak berbicara, menyebar fitnah, tidak memberi dukungan (Buss dalam Karim, 2019).

Konseling humanistik dapat membantu peserta didik dalam memahami dirinya, dengan melakukan layanan konseling humanstik peserta didik akan diberikan pemahaman bagaimana memahami potensi dirinya, menerima dirinya, bersikap dan berperilaku yang sesuai dengan dirinya dan lingkungan, sehingga peserta didik dapat menonjolkan perilaku, sikap hingga berbicara yang lebih baik. Dari uraian di atas dapat dipahami bahwa tugas seorang guru pembimbing adalah melaksanakan bimbingan dan konseling yang sesuai dengan kondisi peserta didiknya, karena dengan adanya guru pembimbing dalam kegiatan belajar mengajar di sekolah akan lebih lengkap.

Berdasarkan hasil observasi yang dilakukan pada tanggal 5 Oktober 2020 di SMA Negeri 7 Mataram dilihat secara langsung bahwa masih banyak siswa yang memiliki perilaku agresif verbal terutama pada siswa kelas XI IPS-4, yang secara jelas perilaku yang nampak, seperti bersorak-sorak, berteriak, pada saat jam pelajaran, mencela teman sebaya, berbicara kasar, menolak berbicara saat ditanya, dan berbicara keras pada saat

\section{KAJIAN PUSTAKA}

Istilah humanistik dalam hubungan dengan konseling memfokuskan pada potensi individu untuk secara aktif memilih dan membuat keputusan tentang hal-hal yang berkaitan dengan dirinya sendiri dan lingkungannya. Professional yang memakai pendekatan humanistik membantu individu untuk meningkatkan pemahaman diri melalui perasaan- yang tidak pantas. Sehingga untuk mengatasi permasalahan-permasalahan agresif verbal tersebut perlu diberikan layanan konseling, salah satunya dengan memberikan layanan konseling humanistik, maka dari itu peneliti perlu melakukan penelitian dengan judul Pengaruh Layanan Konseling Humanistik Terhadap Perilaku Agresif Pada Siswa Kelas XI IPS-4 di SMA Negeri 7 Mataram Tahun Pelajaran 2020/2021.

Berdasarkan gejala-gejala dan fenomena yang telah disebutkan di atas, maka penulis tertarik ingin melakukan suatu penelitian ilmiah dengan judul Pengaruh Layanan Konseling Humanistik Terhadap Perilaku Agresif Pada Siswa Kelas XI IPS-4 di SMA Negeri 7 Mataram Tahun Pelajaran 2020/2021. Hipotesis yang ditawarkan dalam penelitian ada dua yaitu, hipotesis (Ha) yang berbunyi "Ada Pengaruh Layanan Konseling Humanistik Terhadap Perilaku Agresif Pada Siswa Kelas XI IPS-4 di SMA Negeri 7 Mataram Tahun Pelajaran 2020/2021". Dan hipotesis (Ho) yang berbunyi "Tidak Ada Pengaruh Layanan Konseling Humanistik Terhadap Perilaku Agresif Pada Siswa Kelas XI IPS-4 di SMA Negeri 7 Mataram Tahun Pelajaran 2020/2021". Selaras dengan rumusan masalah di atas, maka tujuan Penelitian ini adalah untuk mengetahui "Pengaruh Layanan Konseling Humanistik Terhadap Perilaku Agresif Pada Siswa Kelas XI IPS-4 di SMA Negeri 7 Mataram Tahun Pelajaran 2020/2021".

perasaan mereka. Istilah humanistik sangat luas dan memfokuskan pada individu sebagai pembuat keputusan dan pencetus pertumbuhan dan perkembangan diri mereka sendiri (Glading dalam Lesmana, 2013). Pendekatan humanistik pada hakikatnya mempercayai bahwa individu memiliki potensi untuk secara aktif memilih dan membuat keputusan bagi dirinya sendiri dan lingkungannya (Corey dalam Lubis, 2015). Pendekatan 
ini sangat menekankan tentang kebebasan yang bertanggug jawab, jadi individu diberikan kebebasan seluas-luasnya dalam melakukan tindakan, tetapi harus berani bertanggung jawab sekalipun mengandung resiko bagi dirinya.

Konseling humanistik merupakan suatu pendekatan yang berfokus pada perkembangan kehidupan yang positif. Konseling humanistik memiliki konsep yang mengarah pada kehidupan sekarang yang akan sangat berpengaruh pada masa depan seseorang, berdasarkan perilaku sekarang yang bisa menentukan nasib masa depannnya (Corey dalam Fitri. 2019). Ahli lain juga berpendapat bahwa konseling humanistik merupakan suatu pendekatan yang bertujuan agar klien mengalami keberadaannya secara otentik dengan menjadi sadar atas keberadaan dan potensi-potensi serta sadar bahwa ia dapat membuka diri dan bertindak sesuai kemampuannya (Primayanti dalam Fitri dkk, 2019). Pendekatan ini terutama adalah suatu sikap yang menekankan pada suatu pemahaman atas manusia. Humanistik memandang manusia sebagai makhluk yang memiliki otoritas atas kehidupan dirinya. Manusia bebas untuk menjadi apa saja dan siapa sesuai keinginannya. Manusia adalah makhluk hidup yang menentukan sendiri apa yang ingin dia lakukan dan sebuah apa yang ingin tidak dia lakukan, karena manusia adalah makhluk yang bertanggung jawab. Asumsi ini menunjukkan bahwa manusia adalah makhluk yang sadar, mandiri, aktif yang dapat menentukan (hampir) segala aktifitas kehidupannya.

Menurut pendekatan PersonCentered, manusia dipandang sebagai insan rasional, makhluk sosial, realistis dan berkembang. Manusia yang memiliki perasaan negatif dan emosi anti-sosial merupakan hasil dari kefrustrasian atas tidak terpenuhinya implus-implus dasar, ide yang berhubungan dengan hirarki kebutuhan Maslow. Contohnya, tingkah laku agresif yang merupakan ekspresi frustasi dari tidak terpenuhinya kebutuhan dasar tentang cinta (love) dan belonging (Thompson dalam Komalasari dkk, 2016). Pendekatan ini juga memandang bahwa manusia memiliki kemampuan untuk merasakan pengalaman, yaitu mengepresikan daripada menekan pikiran-pikiran yang tidak sesuai dalam kehidupan ke arah yang lebih sesuai. Menurut Rogers, manusia melangkah maju menuju aktualisasi diri seiring dengan maju ke arah penyesuaian psikologis (psychological adjusment). Konselor dengan pendekatan personcentered percaya bahwa manusia adalah: Memiliki worth dan dignity dalam diri sehingga ia layak diberikan penghargaan (respect). Memiliki kapasitas dan hal untuk mengatur dirinya sendiri dan mendapat kesempatan dan membuat penilaian yang bijaksana. Dapat memilih nilainya sendiri. Dapat belajar untuk bertanggung jawab secara konstruktif. Memiliki kapasitas untuk mengatasi perasaan, pikiran dan tingkah lakunya Memiliki potensi untuk berubah secara konstruktif dan dapat berkembang kea rah hidup yang penuh dan memuaskan (full and satisfiying life) dengan kata lain aktualisasi diri (self-actualisations) (Thompson dalam Komalasari dkk, 2016).

Humanistik adalah suatu teori yang tertuju pada masalah bagaimana tiap individu dipengaruhi dan dibimbing oleh maksud-maksud pribadi yang mereka hubungkan kepada pengalamanpengalaman mereka sendiri (Rochem dalam Fitri dkk, 2011). Konseling humanistik berfokus pada perkembangan kehidupan yang positif. Konseling humanistik memiliki konsep yang mengarah pada kehidupan sekarang yang akan sangat berpengaruh pada masa depan seseorang, berdasarkan perilaku sekarang yang bisa menentukan nasib masa depannya. Konseling humanistik 
membuat kondisi-kondisi dalam memaksimalkan kesadaran diri guna menghapus penghambat dalam mengoptimalkan potensi, dan memilih jalan untuk mencapai kebebasan yang harus diikuti oleh tanggung jawab secara sadar (Corey dalam Fitri dkk, 2019). Konseling humanistik membuka jalan untuk mengalami dan melihat keterkaitan dari hal-hal yang sudah ada, bahkan ideide yang pada akhirnya disatukan dalam upaya mereka yang berfokus pada hati untuk mengurangi penderitaan yang tidak perlu dan memperluas kapasitas manusia untuk kesadaran, pertumbuhan dan kehidupan yang bermakna (Felder dalam Fitri dkk, 2019).

Secara lebih spesifik, konseling humanistik bertujuan membantu klien untuk memulai perjalanan investigasi dirinya, dengan tujuan: memahami konflik tak sadarnya, mengidentifikasi mekanisme pertahanan diri yang salah, menemukan pengaruh, mengurangi tingkat kecemasan berlebihan dalam bermasyarakat, menegembangkan cara untuk mengatasi kecemasan yang berasal dari pikiran-pikiran individu (May dalam Fitri dkk, 2019) dan konseling humanistik juga bertujuan agar klien mengalami keberadaanya secara otentik dengan menjadi sadar atas keberadaan dan potensi-potensi serta sadar bahwa ia dapat membuka diri dan bertindak sesuai kemampuannya (Primayanti dalam Fitri dkk, 2019).

Istilah agresif sering diartikan dalam percakapan sehari-hari untuk menerangkan sejumlah besar perilaku kasar atau keras. Di dalam istilah yang digunakan tersebut kebanyakan didalamnya mengandung akibat ataupun kerugian bagi orang lain. Erat hubungannya dengan kemarahan karena kemarahan dapat terjadi jika orang tidak memperoleh apa yang mereka inginkan. Emosi, marah akan berkembang jika orang mendapat ancaman bahwa mereka tidak akan mendapatkan apa yang mereka kehendaki dan kemungkinan pula akan terjadi pemaksaan kehendak atas orang atau objek lain dan kemarahan akan berkembang menuju agresif.

Sikap agresif biasanya diwujudkan dalam bentuk menyerang, menyakiti, atau melawan orang lain secara fisik ataupun verbal. (Moena dalam Rahman, 2015). Ahli lain juga berpendapat bahwa agresif adalah tingkah laku individu yang ditujukan untuk melukai atau mencelakakan individu lain yang tidak menginginkan datangnya tingkah laku tersebut (Baron, dalam Dayakisni dan Hudaniah, 2012) Perilaku agresif verbal merupakan suatu perilaku yang dilakukan untuk menyakiti, mengancam atau membahayakan individu-individu atau objek-objek yang menjadi sasaran tersebut secara verbal atau melalui kata-kata dan langsung ataupun tidak langsung, seperti memaki, menolak berbicara, menyebar fitnah, tidak memberi dukungan (Buss dalam Karim, 2019). Perilaku agresif verbal merupakan perilaku menghina atau menyakiti yang dapat ditunjukkan dengan berteriak, berdebat, memaki, dan menggunakan kata sarkasme (Ahsan dalam Lalitya dan Mayke, 2019). Dari beberapa pendapat para ahli di atas maka dapat disimpulkan bahwa perilaku agresif verbal merupakan bentuk perilaku agresif yang dilakukan untuk menyakiti, mengancam atau membahayakan individu-individu atau objek-objek yang menjadi sasarannya secara verbal atau dengan kata-kata langsun ataupun tidak langsung. Sedangkan secara umumnya perilaku agresif dapat disimpulkan sebagai suatu perbuatan yang dilakukan oleh individu tehadap seseorang menggunakan benda atau ucapan, sengaja maupun tidak sengaja yang bisa membuat seseorang tersebut merasa tidak nyaman baik dari segi fisik maupun mental. 
Ada beberapa kelompok agresif verbal (Buss dalam Dayaksini dan Hudaniah, 2012) antara lain sebagai berikut: Agresif verbal aktif langsung, yaitu tindakan agresif verbal yang dilakukan oleh individu atau kelompok dengan cara berhadapan secara langsung dengan individu atau kelompok lain seperti menghina, memaki, memaki, marah dan mengumpat. Agresif verbal pasif langsung, yaitu tindakan agresif verbal yang dilakukan oleh individu atau kelompok dengan cara berhadapan dengan individu atau kelompok lain namun tidak terjadi kontak verbal secara langsung, seperti menolak berbicara, bungkam. Agresif verbal aktif tidak langsung, yaitu tindakan agresif verbal yang dilakukan oleh individu atau kelompok dengan cara tidak berhadapan secara langsung dengan individu atau kelompok lain yang menjadi targetnya, seperti memfitnah dan mengadu domba. Agresif verbal pasif tidak langsung, yaitu tindakan agresif verbal yang dilakukan oleh individu atau kelompok dengan cara tidak berhadapan dengan individu atau kelompok lain yang menjadi targetnya Dalam penelitian ini jenis penelitian yang digunakan peneliti adalah penelitian kuantitatif yang dimana memerlukan perhitungan. Maka dalam penelitian ini akan dijabarkan suatu teori-teori yang berfungsi untuk menjelaskan segala rancangan-rancangan penelitian yang akan dijalankan. Berdasarkan metode pendekatan atau jenis penelitian ini, maka penelitian ini menggunakan metode pendekatan eksperimen. Manfaat dari rancangan penelitian adalah untuk menggambarkan skema penelitian. Penelitian ini akan menggambarkan secara sistematis, akurat, actual tentang fakta yang akan diselidiki tentang "Pengaruh Layanan Konseling Humanistik Terhadap Perilaku Agresif Pada Siswa Kelas XI IPS-4 di SMAN 7 Mataram". dan tidak terjadi kontak verbal secara langsung, seperti tidak memberi dukungan, tidak menggunakan hak suara.

Respons yang kurang baik terhadap suatu masalah atau keadaan menyebabkan tubuh memperoduksi berbagai hal negative sehingga memicu munculnya berbagai gangguan pada organ-organ tubuh. Dampak minimal yang ditimbulkan ialah membuat sarafsaraf otak menjadi tertekan atau stress disebabkan adanya energy negative yang menjalar, bagi orang yang terbiasa bersikap agresif maupun agresif verbal, pelampiasan stress tentu dilakukan dengan cara-cara menyerang pihak lain. Jika hal demikian terjadi secara terus menerus, sebagaimana telah dibuktikan melalui ilmu medis dan penelitian, stress dapat menyebabkan berbagai macam penyakit (dalam Yulianto, 2015) sebagai berikut: (1) Kelainan jantung; (2) Gangguan pada pancreas; (3) Gangguan saraf otak; (4) Gangguan pada perut; (5) Usus bermasalah, serta (6) Insomnia dan sebagainya.

\section{METODE PENELITIAN}

Dalam penelitian ini terdapat dua variabel, yaitu kondseling Humanistik sebagai variabel bebas (indevendent variable) dan prilaku agresif sebagai variabel terikat (devendent variable). Variabel bebas merupakan variabel yang mempengaruhi atau yang menjadi sebab perubahannya atau timbulnya variabel terikat. Variabel ini sering disebut sebagai variabel pengaruh, sebab berfungsi mempengaruhi variabel lain. Sedangkan variabel terikat merupakan variabel yang dipengaruhi atau yang menjadi akibat, karena adanya variabel bebas (Sugiyono dalam Sari, 2016). Penelitian ini menggunakan desain penelitian one group pree test dan post test design dimana dalam rancangan ini hanya terdapat satu kelompok subyek yaitu kelompok eksperimen sebagai kelompok yang 
dikenakan perlakuan. Pertama-tama dilakukan pengukuran terhadap kelompok eksperimen, lalu dikenakan perlakuan berupa layanan konseling humanistik dalam jangka jangka waktu tertentu, kemudian dilakukan pengukuran untuk kedua kalinya dengan tujuan untuk mengetahui perbedaan hasil pree test sebelum diberikan perlakuan dengan post test setelah diberikan perlakuan.

Populasi merupakan wilayah generalisasi yang terdiri atas obyek/subyek yang mempunyai kuantitas dan karakteristik tertentu yang diterapkan oleh peneliti untuk dipelajari dan kemudian ditarik kesimpulannya (Sugiyono, 2019). Sedangkan ahli lain berpendapat bahwa populasi adalah keseluruhan subyek penelitian (Suharsimi Arikunto dalam Hatmoko, 2015). Berdasarkan pendapat para ahli di atas maka dapat disimpulkan bahwa populasi bukan hanya orang, tetapi obyek dan benda-benda alam yang lain. Populasi juga bukan sekedar jumlah yang ada pada obyek/subyek yang dipelajari, tetapi meliputi seluruh karakteristik/sifat yang dimililki oleh subyek/obyek itu. Kaitannya dengan penelitian ini, yang menjadi populasi adalah siswa kelas XI IPS-4 yang berjumlah sebanyak 28 orang. Pada prinsipnya meneliti adalah melakukan pengukuran terhadap fenomena sosial maupun alam. Meneliti dengan data yang sudah ada lebih tepat kalau dinamakan membuat laporan daripada penelitian, namun demikian Dalam penelitian ini, awalnya peneliti melakukan observasi, wawancara serta melakukan pengenalan lingkungan prasekolah di SMA Negeri 7 Mataram pada tanggal 5 oktober 2020. Selama menjalankan pengenalan lingkungan prasekolah (PLP) banyak dijumpai siswa yang berperilaku kurang sopan, baik di dalam kelas, maupun diluar kelas, maka dari itu peneliti berinisiatif mengangkat permasalahan ini untuk diatasi. Dalam hal dalam skala yang paing rendah laporan juga dapat dinyatakan sebagai bentuk penelitian (Emory dalam Sugiyono, 2019). Instrumen penelitian adalah suatu alat yang digunakan untuk mengukur fenomena alam maupun sosial yang diamati (Sugiyono, 2019). Dari pengertian tersebut dapat dipahami bahwa instrument merupakan suatu alat bantu yang digunakan oleh peneliti dalam menggunakan metode pengumpulan data secara sistematis dan lebih mudah. Instrument penelitian menempati posisi teramat penting dalam hal bagaimana dan apa yang harus dilakukan untuk memperoleh data dilapangan.

Dalam penelitian ini metode pengumpulan data yang digunakan adalah metode angket sebagai metode pokok, metode dokumentasi, metode wawancara dan metode observasi sebagai metode pelengkap. Dalam penelitian kuantitatif, analisis data merupakan kegiatan setelah data dari seluruh responden atau sumber data lain terkumpul. Teknik analisis data dalam penelitian kuantitatif menggunakan statistik, terdapat beberapa dua macam statistik yang digunakan untuk analisis data dalam penelitian, yaitu statistik deskriptif dan statistik inferensial (Sugiyono 2018). Terkait dengan penelitian ini maka metode analisis data yang digunakan adalah analisis data $t$-test indevendent dengan rumus pendek (shot method).

\section{HASIL DAN PEMBAHASAN}

ini peneliti mengambil populasi sebanyak 28 siswa yang berada pada kelas XI IPS-4 di SMA Negeri 7 Mataram lalu 8 siswa dijadikan sampel dengan diambilnya nilai paling tinggi pada siswa yang berperilaku agresif yang akan dirubah, sebelum memberikan treatment terlebih dahulu peneliti memberikan pre-tes kepada seluruh siswa dengan jumlah populasi yang sudah ditentukan yakni sebanyak 28siswa. Angket pre-test disebarkan 
melalui link yang dibuat menggunkan google form dengan jumlah 25butir pernyataan dan 3 option jawaban, setelah melakukan pre-tes barulah peneliti menganalisis data siswa yang akan dijadikan sampel lalu diberikan perlakuan treatment untuk mendapatkan perubahan terhadap perilaku agresif siswa tersebut.

Mengingat konsdisi saat ini yang tidak memperbolehkan kegiatan-kegiatan yang meninmbukan banyak kerumunan yang dapat menyebabkan semakin maraknya penularan virus Covid-19 maka peneliti memberikan treatmen dengan cara konseling individu sesuai dengan protokol kesehatan dan treatment dilakukan selama tiga kali konseling terhadap siswa, dengan demikian hasil dari treatment ini berhasil, dimana perilaku agresif pada siswa tersebut menurun. Maka dari itu sesuai dengan landasan teori yang telah diajukan penelitian ini sejalan dengan penelitian yang telah dilakukan oleh RatuMisqiyah 2018 dengan menggunakan "Teknik Konseling Humanistik Dalam Mengatasi Perilaku Agresif Pada Remaja Dengan Orang Tua Tunggal"

Sesuai dengan data yang diperoleh dan uji statistic yang dilakkan dengan rumus $t$-test, ternyata ditemukan hasil bahwa $t_{\text {hitung }}$ lebih besar dari pada tabel, maka dari itu hipotesis nol (Ho) yang berbunyi: Tidak ada pengaruh Layanan Konseling Humanistik Terhadap Perilaku Pada Siswa Kelas XI IPS-4 di SMA Negeri 7 Mataram Tahun Pelajaran 2020/2021 ditolak, dan hipotesis alternatif (Ha) yang berbunya: Ada Pengaruh Layanan Konselig Humanistik Terhadap Perilaku Agresif Pada Siswa Kelas XI IPS-4 di SMA Negeri 7 Mataram Tahun Pelajaran 2020/2021 diterima, serta penelitian ini dapat dinyatakan "Signifikan".

Berdasarkan hasil analisis data dan pembahasan BAB IV maka dapat disimpulkan bahwa: Ada Pengaruh
Perilaku agresif verbal merupakan suatu bentuk perilaku menyakiti orang lain yang dapat meyebabkan kerusakan mental. Sama halnya dalam hal ini banyak peserta didik kelas XI IPS-4 berperilaku agresif verbal seperti berbicara kasar, menolak berbicara saat ditanya, berbicara keras saat jam pelajaran, hingga mencela teman sebayanya. Oleh karena itu diperlukan bimbingan dan konseling untuk mengurangi perilaku agresif verbal peserta didik tersebut, dan konseling humanistik merupakan konseling yang tepat untuk mengatasi perilaku agresif verbalnya, karena konseling humanistik merupakan suatu konseling yang berfokus pada perkembangan kehidupan manusia yang positif. Maka melalui konseling ini peserta didik akan diberikan pemahaman atas dirinya sebagai makhluk yang memiliki kemampuan berfikir secara sadar dan irasional serta tanggung jawab terhadap hidup dan perbuatan mereka sendiri. Jadi dengan diberikannya konseling humanistik dengan secara individu diharapkan dapat mengurangi bahkan menghilangkan perilaku agresif verbal pada peserta didik. Dengan demikian layanan Konseling Humanistik mempunyai peranan yang positif dalam membantu siswa yang mengalami masalah terkait dengan perilaku agresif. Kepada pihak sekolah terutama pada guru bimbingan dan konseling, disarankan agar tetap melaksanakan konseling dengan menggunakan layanan konseling humanistik yang dilaksanakan secara terprogram, karena telah terbukti bahwa layanan konselig humanistik bisa membantu siswa yang memiliki perilaku agresif.

\section{KESIMPULAN DAN SARAN}

Layanan Konseling Humanitik Terhadap Perilaku Agresif Pada Siswa Kelas XI IPS-4 di SMA Negeri 7 Mataram Tahun 
Pelajaran 2020/2021. Dengan kata lain bahwa hipotesis nol (Ho) ditolak dan hipotesis alternative (Ha) diterima. Hal ini dapat dilihat dari hasil penelitian yang menunjukkan bahwa nilai $t_{\text {hitung }}$ dengan jumlah 5,543 dan $t_{\text {tabel }}$ dengan signifikasi $5 \%$ dengan $\mathrm{N}=8-1=7$ lebih besar dari nilai tabel yaitu $(5,543>2,365)$ sehingga penelitian dinyatakan "Signifikan".

Berdasarkan kesimpulan di atas, maka dapat diajukan beberapa saran sebagai berikut: Bagi Kepala Sekolah, supaya lebih memperhatikan fasilitas yang dibutuhkan oleh guru bimbingan dan konseling demi terlaksananya kegiatan konseling yang efektif bagi siswa-siswi di SMA Negeri 7 Mataram yang lebih baik. Bagi guru BK, pelaksanaan layanan

\section{DAFTAR PUSTAKA}

Adhi, Ni Ketut J. 2017. Efektifitas Konseling Eksistensi Humanistik Dengan Kebermaknaan Hidup Pada Tunanetra. Jurnal Psikologi, Vol (1), 42-45

Dayaksini, Tri dan Hudaniah. 2009. Psikologi Sosial. Malang: UMM Press

Ernawati, Afni. 2008. Pengaruh Bimbingan Agama Islam Terhadap Perilaku Agresif Anak di Panti Asuhan Yatim Darun AlAitam Moga Pemalang. Fakultas Dakwah. Institut Agama Islam Negeri (IAIN) Walisongo Semarang. Semarang

Fitri, Qawiyyan, dkk. 2019. Penerapan Pendekatan Konseling Eksistensi Humanistik Untuk Mengurangi Perilaku Hedonis Siswa di SMAN 10 Makasar. Jurnal Ilmiah Psikologi. Vol 6 (1), 41-44

Hapsari, Yohana Desy D. 2019. Hubungan Antara Tekanan Teman Sebaya dengan Agresi Verbal Remaja Putra di Sekolah Berasrama. Fakultas Psikologi. konseling humanistik diharapkan dilakukan secara terus menerus dan terprogram, serta lebih memperhatikan perilaku setiap siswa agar dapat. mengatasi perilaku yang tidak baik. Bagi siswa, bisa memanfaatkan layanan konseling humanistik yang telah diprogramkan oleh guru BK sebagai layanan konsultasi atas segala permasalahan yang dihadapinya agar perilaku agresif siswa tidak mengganggu lingkungannya, kegitannya hingga dirinya sendiri. Bagi peneliti lain, hasil penelitian ini dapat dilakukan penelitian yang lebih luas menegenai hal-hal yang belum terungkap ataupun masih kurang dalam penelitian ini.

Universitas Sanata Dharma. Yogyakarta

Hariadi Ahmad dan Aluh Hartati. 2016. Panduan Pelatihan Self Advocacy Siswa SMP untuk Konselor Sekolah. LPP Mandala. Mataram

Hariadi Ahmad, dan Yolana Oktaviani. 2019. Pengaruh Teknik Self Instruction Terhadap Harga Diri Siswa Kelas Kelas XI di SMK Negeri 1 Lingsar Kabupaten Lombok Barat. Realita Jurnal Bimbingan dan Konseling Vol. 4 No 2 Edisi Oktober 2019. Hal 806 - 815. Prodi Bimbingan dan Konseling Fakultas Ilmu Pendidikan IKIP Mataram.

Hariadi Ahmad, Lidya Wurru dan Jessica Festy Maharani. 2021. Hubungan antara Keharmonisan Keluarga dengan Perilaku Agresif pada Siswa Madrasah Aliyah Raudlatusshibyan NW Belencong. Realita Jurnal Bimbingan dan Konseling Vol. 6 No 1 Edisi April 2021. Hal 1205 - 1212. Prodi Bimbingan dan Konseling Fakultas Ilmu Pendidikan dan 
Psikologi Universitas Pendidikan Mandalika.

Hasrul dan Hariadi Ahmad. 2021. Mereduksi Prasangka Etnik Siswa dengan Teknik Restructuing Cognitive Suatu Krangka Konseptual. Realita Jurnal Bimbingan dan Konseling Vol. 6 No 1 Edisi April 2021. Hal 1213 1222. Prodi Bimbingan dan Konseling Fakultas Ilmu Pendidikan dan Psikologi Universitas Pendidikan Mandalika.

Hatmoko, Jefri H. 2015. Survei Minat dan Motivasi Siswa Putri Terhadap Mata Pelajaran Penjasorkes Di SMK Se-Kota Salatiga Tahun 2013. Jurnal Of Physical Education, Sport, Health And Recreations. 1729-1736

Karim, Azka F. 2019. Hubungan Antara Kontrol Diri Dengan Perilaku Agresif Verbal Pada Siswa di SMP Negeri 4 Ungaran. Fakultas Ilmu Pendidikan. Universitas Negeri Semarang. Semarang

Komalasari, Gantina., dkk. 2016. Teori dan Teknik Konseling. Jakarta: PT INDEKS

Kursin, 2005. Efektifitas Lyanan Konseling Kelompok Dalam Mengurang Perilaku Agresif Siswa Panti Pamardi Putra Mandiri Semarang Tahun 2004/2005. Fakultas Ilmu Pendidikan. Universitas Negeri Semarang. Semarang

Lalitya, Lecya, Tedjasaputra Meyke S. 2019. Efektifitas Differentiated Reinforcement of Incompatible Behaviour (Diri) Dalam Menurunkan Perilaku Agresi Verbal Pada Remaja Dengan Moderate Intelectual Disability. Jurnal Psikologi Sains dan Profesi. Vol 3 (2) 105-113
Lesmana, Jeanette M. 2013. Dasar-Dasar Konseling. Jakarta: Universitas Indonesia

Lestari, Novita D. 2020. Pengaruh Bimbingan Kelompok Terhadap Kurangnya Sikap Asertif Siswa Kelas VII di SMPN 4 Mataram. Fakultas Ilmu Pendidikan. Undikma Mataram. Mataram

Lubis, Namora Lumongga. 2011. Memahami Dasar-Dasar Konseling. Jakarta: Perpustakaan Nasional

Mahmudah, Siti. 2012. Psikologi Sosial Teori dan Model Penelitian. UINMaliki Press

Misqiyah, Ratu. 2018. Teknik Konseling Humanistik Dalam Mengatasi Perilaku Agresif Remaja Dengan Orangtua Tunggal. Fakultas Dakwah. Universitas Islam Negeri Sultan Maulana Hasanuddin Banten. Banten

Rahman, Agus A. 2014. Psikologi Sosial Integrasi Pengetahuan Wahyu dan Pegetahuan Empirik. Jakarta: Rajawali Pers

Rosada, Ulfa D. Model Pendekatan Konseling Client Centered dan Penerapannya Dalam Praktik. 1425

Sari, Rohana K. 2016. Pengaruh Layanan Bimbingan Kelompok Terhadap Perilaku Sgresif Siswa Pada Kelas XI IPS di SMA Negeri 7 Mataram. Fakultas Ilmu Pendidikan. Ikip Mataram. Mataram

Sarwo, W. S. 2009. Psikologi Sosial. Jakarta: Satemba Humanika

Sudani, Ni Ketut., dkk. Penerapan Konseling Eksistensial Humanistik Teknik Pemodelan Untuk Meningkatkan Perilaku Tanggung Jawab Belajar Siswa Kelas VIII E SMP Negeri 1 Sukasada.

Sugiyono. 2016. Statistika Untuk Penelitian. Bandung: Alfabeta 
Jurnal Realita Bimbingan dan Konseling (JRbk)

Volume 6 Nomor 2 Edisi Oktober 2021

Bimbingan dan Konseling FIPP Universitas Pendidikan Mandalika

https://e-journal.undikma.ac.id/index.php/realita

Sugiyono. 2018. Metode Penelitian Yulianto, Herman. 2015. Mau Sehat

Kuantitatif, Kualitatif dan $R \& D$.

Bandung: Alfabeta

Sugiyono. 2019. Metode Penelitian

Kuantitatif dan Kualitatif dan

$R \& D$. Bandung: Alfabeta
Hilangkan Sikap Burukmu.

Yogyakarta: Perpustakaan

Nasional 


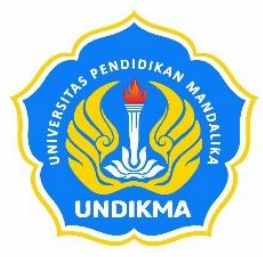

\section{UNIVERSITAS PENDIDIKAN MANDALIKA FAKULTAS ILMU PENDIDIKAN DAN PSIKOLOGI PROGRAM STUDI BIMBINGAN DAN KONSELING Jurnal Realita}

Gedung Dwitiya Lt.3. Jln Pemuda 59A Mataram-NTB 83125 Tlp (0370) 638991 e-mail: realita@undikma.ac.id; web: e-journal.undikma.ac.id

\section{PEDOMAN PENULISAN}

1. Naskah merupakan hasil penelitian, pengembangan atau kajian kepustakaan di bidang pendidikan, pengajaran, pembelajaran, bimbingan dan konseling, dan Psikologi

2. Naskah merupakan tulisan asli penulis dan belum pernah dipublikasikan sebelumnya dalam jurnal ilmiah lain,

3. Naskah dapat ditulis dalam Bahasa Indonesia atau Bahasa Inggris.

4. Penulisan naskah mengikuti ketentuan sebagai berikut:

$\begin{array}{llll}\text { Program } & \text { MS Word } & \text { Margin kiri } & 3.17 \mathrm{~cm} \\ \text { Font } & \text { Times New Roman } & \text { Margin kanan } & 3.17 \mathrm{~cm} \\ \text { Size } & 12 & \text { Margin atas } & 2.54 \mathrm{~cm} \\ \text { Spasi } & 1.0 & \text { Margin bawah } & 2.54 \mathrm{~cm} \\ \text { Ukuran kertas } & \text { A4 } & \text { Maksimum 20 halaman }\end{array}$

5. Naskah ditulis dengan sistematika sebagai berikut: Judul (huruf biasa dan dicetak tebal), nama-nama penulis (tanpa gelar akademis), instansi penulis (program studi, jurusan, universitas), email dan nomor telpon penulis, abstrak, kata kunci, pendahuluan (tanpa sub-judul), metode penelitian (tanpa sub-judul), hasil dan pembahasan, simpulan dan saran (tanpa sub-judul), dan daftar pustaka.

Judul secara ringkas dan jelas menggambarkan isi tulisan dan ditulis dalam huruf kapital. Keterangan tulisan berupa hasil penelitian dari sumber dana tertentu dapat dibuat dalam bentuk catatan kaki. Fotocopy halaman pengesahan laporan penelitian tersebut harus dilampirkan pada draf artikel.

Nama-nama penulis ditulis lengkap tanpa gelar akademis.

Alamat instansi penulis ditulis lengkap berupa nama sekolah atau program studi, nama jurusan dan nama perguruan tinggi. Penulis yang tidak berafiliasi pada sekolah atau perguruan tinggi dapat menyertakan alamat surat elektronik dan nomor telpon.

Abstrak ditulis dalam 2 (dua) bahasa: Bahasa Inggris dan Bahasa Indonesia. Naskah berbahasa Inggris didahului abstrak berbahasa Indonesia. Naskah berbahasa Indonesia didahului abstrak berbahasa Inggris. Panjang abstrak tidak lebih dari 200 kata. Jika diperlukan, tim redaksi dapat menyediakan bantuan penerjemahan abstrak kedalam bahasa Inggris.

Kata kunci (key words) dalam bahasa yang sesuai dengan bahasa yang dipergunakan dalam naskah tulisan dan berisi 3-5 kata yang benar-benar dipergunakan dalam naskah tulisan.

Daftar Pustaka ditulis dengan berpedoman pada Pedoman Penulisan Karya Ilmiah Universitas Pendidikan Mandalika. 


\begin{tabular}{|c|c|c|c|c|c|}
\hline & & & & \\
JURNAL & VOLUME & NOMOR & EDISI & HALAMAN & P ISSN : 2503 - 1708 \\
REALITA & 6 & 2 & Oktober 2021 & $1326-1430$ & E ISSN : 2722 - 7340 \\
& & & & \\
\hline
\end{tabular}

Alamat Qedaksi:

Program Studi Bimbingan dan Konseling Fakultas Ilmu Pendidikan dan Psikologi

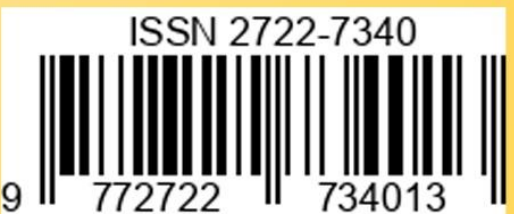

Universitas Pendidikan Mandalika

Gedung Dwitiya, Lt. 3 Jalan Pemuda No. 59A Mataram Telp. (0370) 638991

Email : realita@undikma.ac.id

Web : e-journal.undikma.ac.id

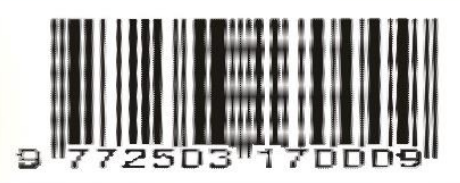

